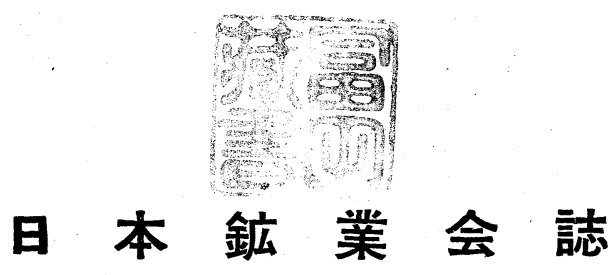

第71卷 第 806 号 昭和 30 年 8 月

\title{
日本鉱業会の創立満 70 年を祝
}

（本会創立70年記念会飞和ける祝辞講演）

日本工学会会長 工博 加茂正雄

まずもつて，本会が明治18年以来70年の間，国家的に また世界的にまことに有意義かっ有効な活動を続けられ まして，会運ますます盛んになつておることに対して， つつしんで抢祝を申し上げます。

私はたまたま日本工学会の会長なしておるという縁故 をもちまして，今日お祝の言葉を申し述へろという御注 交であります。光栄しごくに感ずる次第でありますが， 私個人といたしましては恐縮千万だと申乙上げるほかは ないのであります。御存じの方もおいでかと思いますが， 私本会の会員になりましてからもう50余年になりますか ら，かなり古いほうでございます。その打䔸をもちまし て特別の恩恵に浴さしめられておるのでありまして,こ の機会に厚く皆さんの御好意に対してお礼を申し述べま する之同時に, 今朝からの総会の席に早くまかり出るこ とのできなかつたことに対しておわびを申し上げます。

御存じの通りに日本工学会は明治12年に, 当時工学守 門の人たちの団体として発足をしたのでありましたが， その後、ろいろ違つた方面の仕事の発展をいたしますに つれて，それぞれ専門の学会がこの日本工学会から別れ て創設されることに相なりました。今日においては工学 に直接関係のある専門学会協会の数が約 16 ばかりに文 んで抢名のであります。それが中心になつて工学会がで きて抢分わけでありますが, メンバーである学会, 協会 を全部並へますと，44ばかりになります。ところがこの 汨本鉣業会は，工学会から別れて設けられた最初の專門 学会でありまして、ただいま会長からの括話の通りに, :明治 18 年に創立されておるのであります。工学会が成 立しましてか5 6 年目に, もうこの日本鉱業会は独立の 会として成り立つたわけであります。これはひつきよう ずるに，日本に抢ける資源の開発並びにとれの精製，さ らにそれの加工によつてできる材料が，日本の工業界に ますます要望される程度が高くなつて来た結果だと申さ なければなら好と思うのでありますが，その工学会から 申しますと，いわ方長男の 70 周年の打祝に，今日私 まかり出ることのできましたことはここれは非常な仕合
せであると申すほかはないのであります。

その当時は私はまだ小学校におつた時代だと思います が，一向様子は存じません。しかしその後のことは多少 私の仕事に関係があるところから存じておることもある のであります。よけいなことのようでありますが，子供 のときのことを昔を偲ぶよすがとして打話をして見ます と，明治 23 年だと思います。憲法が制定され，国会が 開設され，市町村制もしかれました。その年に偶々私は 中学校で銅の精鍊の話を聞いたので，そのことをうちへ 䚻つて話しましたら，そうかそれじや実地を見せてやろ うということで—当時親父が愛媛県の新居郡の錊石銅 山というのをやっていました。ちよう民゙市町村制がしか れた当時に親父がそこにおつたからでありましよう。加 茂村という名前がついたのであります一今日でも侗加

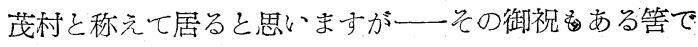
ちようどいいから打前連れて行ってやろうということ で，23年の夏に連れて行かれました。ただいまでもごら んの通りの小男でありますが，当時はまだ14才であり ますので，むつと小さかつたろうと思います。それが坑 (しき)の中に大るとなかなか立つて歩くことができない のであります。古い方は御経験があると思いますが，层 の所に菜であんだ蒲団の㥞なもの（当てしこ）を締めつ け穼して，途中で休むにも，採鉱の現場を見るどきも， なかなか立つているわけにはいか好ら，それを敷いて 腰を掛けるのに便することとし，手にはカンテラを下げ て大つたのでありますが，坑内というものはなかなかえ らいものだなという感じを持たせられました。出て来て その話をしましたところが，いわく、ここはまことに小 さな鉱山であるからそう言うのだが,別子に行つてみろ， なかなかえらいものだ，参考のために別子も見ろという ことでありました。そこで当時轨夫長をしておりました 鄉户という男の案内で山越えをして別子に参りました。 ここはもう200年も仕事をしておるのだから，やき釜の 煙でもつて木はほとんど枯れて何にもない。別子では少 乙風が吹けば石が飛ぶというような状態であるがらて 
のつもりで行けということでありました。行つてみます と，別子の坑内は私が立つて歩小てさしつかえのないよ うなところが相当にあつたのでありますが，やはり同し だなと思いましたのはやき釜です。石を四角く積んで野 天で鉝石を焼く，同しことが別子でも行なわれて居る。 唯その規模が大きいのと，山が古いということだけの違 いであるように感したのであります。

それから約 10 年たつており寺すが，大学范出てから 3 年目に小坂の銅山に参りましたとき竹内維辰君, 小平 浪平君の 2 人が一緒に山の珤で寝起きをしておりまし た。竹内君と私はちようど中学校時代一緒であつたので すが，君，僕が1つ新しいことをやつたから見万という のです。彼の言葉によるとせルフパイラィテック・スメ ルテングと言つたと思いますが，一とにかく相当大きな 炬に鉱石を容れて，別に然料を加えないで的一ストし ている、というように聞きましたがー，僕はこれを始め でだ1週間にしかならないのだが，相当に成績が上つ ているから，将来大分これが使われることになるでと言 つて抢りました。これがいか的るやき釜の大分改良され たもの在見た最初でありました。その後, 何 10 年かた ちまして，1932 年（昭和 7 年）に例のサド心゙リー（加奈 陀）のカッパークリッフといいますが，ニッヶル・マイ ン存見に参りました。これには実は警いたのであります。 坑内を案内するということで，い小いよ坑内に入るとい うときになつても，坑内服は着せてくれません。案内の 先生は只のま立入つて行きます。こつちは旅行中であま りきたないなりをして打りませんでしたのでこれで坑 内在引張廻されては迷惑千万だと思いましたがどうも いたし方ないのでついて行きました。ところが篤いたこ とに坑内はこの建物の前の道も同じであります。電車は 通つている。休憩所もあれば便所もある。電灯はこうこ うとついている。天井は見上げるくらい高い。シルク・ ハットにフロックコートで大つてもさしつかえないとい うような状態でありました。私の寡い見聞から申します とお玄らくこれは世界一大きい鉣山だ庸してもい いかと思うのであります。それでただ大きいなという感 じを持つて出て来ただけでありましたけれども，オフィ スに行きますを、毞うだあの煙突を見たかというのです。 なかなか大きな煙笑だなと思つたと言いましたら，お前 気がつかなかつたかもしれないが，あの煙突はあの近辺 にある鉣山従業員の社宅，—レンガ作りでありますが， 一その家がそつくり大るのだどということでありまし た。1番上の直径が約 70 尺ばかりあるのだ，てうかそ んなに大きいということは感じなからたがと申しました ら，この写真を見ろということで写真を見ると，その煙 突の回りに家がたくさんあるのでありますが，確かにえ の家を 2 つらい一緒に入れても這入るくらいな大きさ
なのであります。これほど大きなきのとは思わなかつた ということを申しましたら，そうか，杂れなら記念に送 つてやろうこいうことで，赛は私はこの写真を今でもう ちに持つて抢り桨す。それと小坂の当時の状態を比心ま すと，鉣山の開発もえらい発展をしたものだなと感した のであります。これはつけ加える必要はないかもしれま せんが，有名なイギリスのモンド大佐があのニッケル・ マインを開発し始めたころは，銅山ということで仕事な 始めた様であります。ところが幾ら掘つてみてもりつば な銅のとれる鉱石が出て来ない。当時ドィッから行つ ていた坑夫たちが，あまり精鍊の成績があがらないもの だから、ニッケル・クーファーというあだ名をつけた。 いわゆる“悪魔銅”の意でありましよう。それがその後 の治金方面の研究によつて御存じのような白いりつぱな ニッケルが出て来るようになつて来て抢るのであります

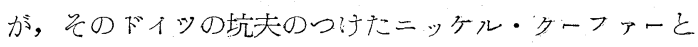
いう名前の頭だけが残つて，今日あの白いメタルはニッ ケルという呼称で通っているの㘷，ということを，この 鉱山の歷史でちよつと見たことがあるのであります。こ れもやはり銅鉱に縁があると考宎ましたのでちよつと申 乙述ヘたわけであります。

こういう発達の状態から考元て見ますと，地下資源》 開発, 精鍊の研究が現代のインダストリーに寄与してい ることの害に夥だしいものであることがよくわかるので 西ります。先刻，会長の括話に明治 26 年という拉言葉 があつたと思いますが，その 26 年は日本でもつて機関 車神戸の工場で初めて作つた年であります。当時鉄材 などはほとんど全部外国から入れたもののように聞いて おりましたが, 日清戦争の結果, その方面の必要を痛感 しで，29 年に製鉄所が始められることになりました。造 船区び航海奨励法というものもできまして, 造船, 海運 方面の活躍をも促がし, 延いては使用原料の処理, 資材 の精選, 改良に大進歩を来しました。私の記譩から言い ますと，日本で鉙山用機械專門のメーカーの生れました のが，ちようどこの頃，即ち明治 34 年に大塚栄吉君の 始められた大冢工場が最初であつたと思います。三田の 松井兵治郎という人の工場で働いておうた人であります が，独立孛して鉱山機峨專門の工場を建てました。それ が今日では日本において最も信頼すべきまたりつぱな 鉱山機械を作る工場として栄えておると思いますが，い わゆる鉣山におおける機械の需要というものがだんだん増 加をして来た 1つの証拠であると考えまするのと同時 に，この大塚工場が栄光るということがまた日本に抢け る鉣業の殷賑を一方に抢いて証拠立てて抢るもののよう に考元ます。

さらに精鍊の方面のことをちよつと申しますと，これ は抢そらく御記憶の方が多いと思いますが，日清戦争の 
結果海軍の増強ということを感じたためでありましよ う。三笠をイギリスで作りました。続いて富士，八島の 両戦艦在イギリスで作りました。そのときに主砲 4 門, これは12in 蚫でありますが、それを備えることにきまつ た。当時イギリスでもイタワアでも13.5inの䣱を採用す ることに方針を決めて抄うたのを，日本で偻々乎とし て12in40日径の砲を便うことにきめたのであります。炎 れが御存じのようにピアノワイヤで砲身を巻、た所謂ワ イャー・倠ンであります。それで実際に使つてみますと この方が射距離も長く, 侵徹力も強いということで, 当

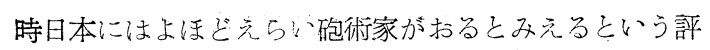
がもつぱら出ておつたのであります。これがそのままず つ之続きまして, 金剛, 比跲, 霧島, 榛名という 2 万 7

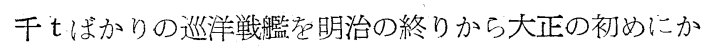
けて作つた際に，たしか 45 年式と唱えて，日本製鋼所 製の 14.5in の施が使われたのでありますが，二れもや はりピアノフォールトを使つて抢るのでありまして、こ れまた世界的に勝れた㿣であつたのであります。これだ けリッパなものが出来るようになつたのは，全く冾金術 進歩の御落でありまして, 畢竟本会々員の方々の御努力 の賜であると申すべきだと心得ます。

近頃工業の進歩は益々高級の材料を要求して止みませ ん。强力で高圧, 高温に堪光, 更に低温に拈々て号質の かわらない。おまけに目方の軽小ものを望んでいます。 これに応ずる原料から，六の精鍊熱処理まで，ことごと く皆様方の打力による外はないのでありまして，本会々 員の方々は現代における工業進歩の鍵を握つておられる とはいうべきであります。

古いことを申乙ますが，たしか 1908 年，明治 41 年と 思小ます。ライト兄弟がニューヨークからオルバーニま でホボソン河に沿うての飛行に成功しました。その翌年, 明治 42 年でありますが，フランスのブレリオが英仏海 峽を飛んだということ老一このとき私はアメリカにお りましたが—新聞紙の報道によりて知りました。それ から 2 年たつて，明治 44 年の夏シカゴでもつてアメリ カの飛行大会がありた。ちようど私はミシ㴶ン・レーク に面したブラックストーンというホテルの5階に抢りま したので，居ながらミシガン・パークでやつて抢りまし た飛行の状態を見ることが出来たのであります。大会は 1週間続小たのですが，4 日目ころにジョンソンという 男が，単葉のいわゆるモフブレーンでもつて飛んでおり ましたが，3千尺くらいのところからきりもみ状態でレ 一クの中に落ちた。そしてそのまま先生は死んでしまっ た。それから2日たつてバッジャーというのがレッドデ ヴィルと呼ぶ赤い翼の複谋の飛行機を操縱して，上ほほ 低空一私の見ておる 5 階よりも相当低いところを飛んで 抢つたように思いますが，連日ウェーヴ型の飛行を続け
ておりました。これでどれだけの抵抗を翼が受けるかと いうことがよくわからなかつた結果ではないかと思いま すが，頮落しました。翼が上向きに折れてしまつたので す。すぐアンビューランス・カーが行つてバッジアを連 れて行くのを私は空から見ておりました。低いところだ つたから大したことはないと思って扔りましたが，夕刊 を見ると死んだと書いてありました。それで最後の日に カーチスのハイドロ・プレーンというて抢りましたがー 実はその前にもカーテスの工場に行つて見ておつたので ありますが，ちように゙カーチスが同じホテルの7階に泊 つて居たので, 扔れのハイドロ・プレーンに乗つてみろ と言うのです。これは乗つてもいいなという妇奇心で出 かけて行つたのでありますが，行つて見る之飛行機のフ レームがみな竹なのであります。継ぎ目は針金でもつて かがつてある。翼は羽二重を加工したものでありますが， これはカーチスの工場で見たのであります。とにかくど うもこんな竹の骨組で，継ぎ目は針金でもつてかがつて あるというようなものに，この1命死托して飛んでみる 気にはなれぬ。ことにジョンソンとバ.ジアが死んだと ころを目の前で見ておるのでありますからままあこれは 遠慮した方がよろしいと考えて，2時半にミルウォ一 キーにたつことになつているし，もう2時近くだから， 願い下げにしょうということで，実は逃げてしまったの であります。その後やはりカーテスの飛行機を持つて来 てミルウォーキーのフェーアでダンカンという男がパイ ロットで飛んで抢りましたが，見事に小河の中へ落ちま した。10分ばかりも出て来なかつたというので，死んだ なと思つたら，無事に本人は上つて来たようであります。 いずれにしても当時の飛行機は竹のフレームで, 継ぎ目 は釬金でかがつてあるというような状態であつたのであ りますが，その後第一次の欧洲大戦で飛行機は大分活躍 しました結果, 元らい発展をいたしまして, 御存じの通 りに今日ではオール・メタルの飛行機というものができ ておるのであります。ところがこれは私が申すまでもな く，いわ切るノンフェラスのアロイ，これが工業上の要 求から発達をして参りまして, フレームはもとよりのこ と，羽もことごとくノンフェラスの軽い合金でできるよ うになつておるのであります。これもまた皆様の御努力 の結晶の1つであると申してもいいと思います。

私は機峨屋でありますので, 機械のことばかりに触れ ますが, 明治 38 年から船の機械として, また陸上の発 電用としてもありますが， ヌービンが使われるようにな りました。初めは羽根はブローンズでできておつたので ありますけれども，だんだん蒸気の温度は高くなる，回 転は早くなるというようなことでありまして，とうてい 普通のスチールなどでは間にあわなくなり，いわゆるア ロイ・スチールが使われるようになりました。当時海軍 
のタービンの羽は金よりも高いぞというような話が出る ところまで行きました。これもよけいなことであります が，日本は軍艦の方でも先鞭をつけて抢るわけです。日 露戦争の結果として日本で計画いたしました戦艦薩摩, これは明治 39 年の 11 月 14 日に横須賀の工廠で進水乙 たのでありますが，これがいわ功る怒級戦艦のプロト・ ヌイプでありました。私がイギリスに参りました時分に， ちように゙ 40 年だつたと思いますが， イギリスのドレッ ドノートができ上つたのであります。日本の薩摩は経費 の都合だつたと思いますが，半年か 1 年おくれて竣工し たので, 実は阷摩に倣つてドレットノートが造られたの でありますけれどる，所謂㐐級戦艦のプロト・タイプは 薩摩であるということがとなえられ得ないようなありさ まになりました。とにかく外見上特にかわつて抢るのは， Ram（衝角）のないことであります。西れをとつてのけ たのは日本が最初で日露戦争の結果, とても軍艦が実戦 においてあのラムを有効に働かせ得る位まで敵艦に接近 することは，将来あり得ない。寧ろその目方だけを武器 か装甲に振り向けたはうが賢いというので，ラムを全然 取つてしまいまして，普通の商船と同じょうな舳にした のであります。それでその後各国みなこの方釬を採るよ うになりました。

次にェンジンの方で申しますと，当時米国でカーチス タービンというのがでてまいりました。アメリカでは従 来のパーソンスタービンやレシプロケーチングエンジン との比較就験をして見ようというので，4千トンの姉旂 通看艦三隻を造って，并の内のセーレムに法カーテス， チェスターにはパーソンス，バーミンガムにはレシプロ 老容秃て実際の運航在行い，乞の結果に基いて将来米国 の軍艦には主機としてぞのタィプを採用するかなきめ うということで進んでおりました。そのときに日本では いち早く 2 万 7 千 500 馬力という当時世界最大の舶用型 カーテス・タービンを安芸(戦), 伊吹(巡洋), の二艦に 採用いたしたのであります。それが動機になりましてイ ギリスではション・ブラウン造船所が，ブラウン・カー チスというタイプを作って，あちらの軍艦に大分大れた のであります。当時大冒険だとの評さへ国外で耳にした こともあつたのでありますが，わが海軍の確信は，世界 の先達海軍国イギリスの一流造船所の研究さへ促がすよ うになつたのであります。そのすぐあとでありますが， 例の金剛がイギリスでできました。今の安芸のときも この金剛のときも私はェンジンの方の製造監督という役 目であちらにおりましたので多少存じておるのでありま すが，金剛を最後といたしまして日本の軍艦は外国で作 つたのは1つもありません。ただ1つ神威という石炭運 搬船がありますが，衣れは電気推進がアメリカの方で発 達をして来たので，兑れを大れてみようということから
と思いますが,クランプの造船所で作つたのであります。 私の数元子の 1 人でありますが元の古市中将（当時大佐 ?）がこの方面の專門家として監督，趈航の任に当りま した。それだけで日本は其後すつかり軍艦においてては独 立需給をしておるのであります。それに使う材料, 機械, ことごとく日本で研究をしたと申していいのでありまし て，并の発達あるいは要求が満たされるようになつたと いうことは，やはり治金のおかげでありまして，最近の エンジニアリングの要求に副うメタル材料はことごとく アロイと申していいと私は考えております。これは今こ ちらにも出て打りますが，次に御話を願います三島徳七 博士の MKステールなぞ，その尤なるもの亡申すべきで， 我国に抢ける冾金研究の勝れて居ること市示す一例で亦 りますが，その前に出来た本多光太郎博士の KS スチー ルも，先刻会長の御話の中に出ました昭和 4 年の万国工 業会議の際に，米国では本多君からその成分在教和つて， いまそこにあるように同性磁力の反撥によりて，磁石を 宙に浮か也る装置を作つて来て，米国主催の宴会の席で 吾々一同に吳れたのでありますが，これには「日本の科 学に対寸る吾々の礼讃」,吾々は全く日本の科学者に降参 したということが刻み込んであります。そのくらいまで こちらの皆さんの御研究の結果は進んで抢つたのであり ます。ただわれわれとして非常に遺憾に感じましたこと は，明治 40 年ころから始まって参りました方スターピ ン汕蒸気タービンにあまり遅れないで発達すべきものだ そいう考で研究を進めたのでありますが，何分にも最初 に入って来ますブスの温度が高いので，それに耐元る材 料がないということのために，その発澾が捗々しくなか つたのであります。ところがこの戦争中日本ほほかから 遮断老されまして，亦りり外国のインフォメーションを 受け取ることのできなかった間に，あちらではどんぞん 高い温度に耐光る材料の研究が進んで参りまして，りっ ぱに $800^{\circ} \mathrm{C}$, 瞬間的ならば $900^{\circ} \mathrm{C} に も$ 達するような温度 にも耐えるものがアメリカでできました。これは私のよ うなしろうとが申さ好でも御存じと思いますが，二ッケ ルだとかクローム・コバルト，タングステン，※リブデ ン、など、いわゆるレーア・メヌル類の混入をいらいろ 調整してみても，なかなか満足なものが得られなからた のが，アレゲニーのルードラム会社で，コロンビューム を 4\%許り加えることによりて（ニッケル $20 \% ，$ クロ 一ム $20 \%$ ，コバルト $20 \%$ ，モリブデン $4 \%$ ，ダングステ ン 4\%，コロンビューム4\%，Mg $2 \%$ 以内， Si 1\%以内 と聞きました）うに $1450^{\circ} \mathrm{F} ， 800^{\circ} \mathrm{C}$ くいの温度に までも耐えるものができるようになりました。元のおか げで今日分スタービンは大一んに発達をいたしておりま す。最近は自動車にも，機関車にもどんどん分スタービ ンを便って打ります。私の受け取りました最近のインフ 
オメーションによると，自動車に使つておるガスダービ ンの翼車の直径は $18 \mathrm{~cm}$ ，すなわち $7 \frac{1}{4}$ inくらいのもの で，それだ毎分 3 万 5 千から 4 万回迴るのだから，その セントりフューガル・フォースはすばらしいものであり ますが，それに耐えるだけの材料がすつかりできるよう になりました。これは全く治金方面の研究の扔がであ りまして, 将来原料と冶金, 工業生産品の設計, 製作に 携わるものは, 御互に特に密接な連絡, 提携を保つて行 くことが，益々必要になつて来ると信じす。

こいうのは現世紀の後半に括、て，産業は過去の半世 紀又は1/4世紀のそれとは，全く比較にならぬくらい急速 な発展を遂げるものと思われ，所要材料に対する要求も ますますふえてくると信ずるからであります。この産業 が大なる加速度で進展する根源は彼の電子力並に原子力 利用の実現であります。原子核の分裂によりて発生され た熱を動力化し得ることは，米，英，ソなどの原子発電 所によりて証拠立てられ，米海軍は彼の原子力潜水艦， ーテラス号を息実用価值のあるものとして居ります。

2,3 年前に私の受け取りました報文の中で，シカゴの 近くのマックマス, ヒューバート天文台のマックマス台 長の言つて居るところによりますと，太陽の表面におい ては，每秒約 200 万トンの物質—ただマテリアルと書 いてあります一が分裂している。その分裂によつて出 て来たとこらの熱が宇宙に放散されておるのであるが, 地球が受け取つて抢る熱量はそのうちの約 4 ポンド分に 相当するだけのものに止まると，そうすると太陽の放射 する熱の僅か10億分の 1 だけを地球が受取つて，わ冯わ

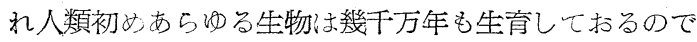
ある。ところが今から14年ばかり前にシカゴで行つた箺 験によりますと，ウラニューム（U235）の原子の分裂に よりて発生した熱は,全くこの太陽熱と同じものであり， しかもその後人閒がれをコントロールし得るようにな つたのであります放ら, 将来これる利用しないのは間違 つて抢る。現に欧米では，既に10力年近くの実験子行つ て前に述心たように，今やその実用期に大ろうとして居 ます。われわれもこれに遅れないように,当然原子力の利 用に進むべきで，えうしさえすれば，産業用の動力など は，何等燃料を用いないで，少量のウラニュームから得 られるのであります。ただ今日においては経済的に，石 炭や石油虑使うのに比へて幾分か心配な点があるようで ありますけれども，更に研究を積み改良を加えれば，こ の点は遠からず克服されて，日本鉱業会が 100 年のお祝 をされる時代においては，おをらく私はもう世の中は原 子力時代になつておるだろうと思つております。3，4年 前から私は19 世紀は石炭の時代であつた，現 20 世紀は 油の時代である。来るへき 21 世紀は，これは原子力の 時代に間違いないということをとなえておるのでありま
すが，一向一般の関心を㫣き得たように思いませんでし た。近ごろになつて漸く大薁の注意が,この平和的利用の 方に向けられて来たように見受けられますので，まこと に結構なことだと思つています。いよいよそうなるとこ れから先の発展は決して過去の50 年 20 年に比へられる ものではなくして，急速に全然変つた産業界とならざる を得ないと思います。さてこの原子核から発生されたえ らい熱をわれわれが利用するということのためには，ま た皆さんの御努力る煩わさなければならないのでありま す。さらに天然資源のいかなるものをこの方面に使うか。 今日に抢いてはテトリウム，カリウムの合金がをの熱の 伝達に使われておる様であり方すか，さらに進んでほか のものも利用されざるを得ないと私は思います。合金に つてもそう值段の高いものげかり使う必要はない。耐 熱にすぐれた性質を持つて抢るもの存造るにも，これま で使つたようなプレッジアス・ヌヌルのほかに，普通の 砂とか，あるいは陶磁器を粉にしたもの乍混ぜても，間 に合う見込があるともいわれております。(Ford会社 Andrews Coocher の言) さらに原子力の発生もウラニ

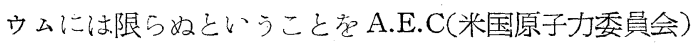
の委員の一人は唱えており学す。皆様の御努力如何によ りょしては，日本にある資源でもつてこの原子力を発生 することができるような時代が決して望み得られないこ とはないと思われ亲す。将来この方面に一そう扐力を入 れていただくことができれば，国のためには非常にけつ こうなことだと思つておるのであり苏す。

実は昨日思い起したのでありますが，4 月25日という のは，英棓を話寸国では特殊の行事のある日となつて居 り衣。April は Latin 語の Aperire (Iōopen) から来 た名前で，木の芽が出る，花が開くの意で，自然植物に はアブラムシなど虫の多くつくこと在免かれませぬ。そ こで25日支 “Robigaria” for averting Mildewと言つ て，植物につく「カビ」を取り去る日とされています。

视賀の席でかようなこと虏申寸の惊，寧ろ差控えるへ きであるかとも思われます氻，日本鉱業会が70年の御祝 いをされる今日が，偶然にもこの「ロビカリア」と一致 して居たということは，一方において70年の有効な順調 な発達觉祝われるのと同時に，長い年月の閒に，ほこり の溜つた妈はないか，白蟻にやられて居る処でもありは しないかということを反省しろという暗示を与えられた ものと考えられても, 決して失われるところはない訳て ありますから，今日の隆昌に甘んぜられませんで，改良 をする，或は更に創意，工夫を施すべき余地のある所は ないかを検討されて，来るへき座業の大革命期に備えら れる基礎を固められるよう心眯けられることを得ますれ ば，今日の祝賀会は大に意義のあるものになるのではな いかと考える次第であります。

(打わり) 